\title{
The Importance of Christian Youth Ministry Involvement in Community Development in the Mayibuye Community
}

\author{
Mawethu Msebi1 \\ 1 University of Pretoria, Hartfield -Pretoria, South Africa
}

\begin{abstract}
This article reports on the findings of the Christian youth ministry involvement in community development in the Mayibuye community (Tembisa-Gauteng Province, South Africa). The article employed the use of Richard Osmer's model of the four tasks of practical theological interpretation in describing and analysing the situation in the Mayibuye community. The tasks sought to give an understanding of what is happening in youth ministry and community development contexts in the Mayibuye community. The study relied on both documentary analysis and in-depth semi-structured interviews. The findings revealed that several socioeconomic challenges antagonize local communities, and young people are the most affected, as they possess a more significant number amongst all community sectors. The findings further discovered that the youth and youth ministry involvement is limited in community development processes amid local communities. In this light, the Mayibuye community has been experiencing a low level of education, gender inequity, unemployment, sexual-related challenges, substance abuse, and illicit conduct amongst the social ills. The study introduced promoting values, enhanced respect for others, driving service with integrity, and more as the benefits of youth ministry involvement in community development. The study also recommended further empirical studies on youth ministry involvement in community development, enhancement of collaboration between local religious communities and government, and engagement of young people in community development processes.
\end{abstract}

Keywords: Community development, illicit conduct, social cohesion, social justice, youth ministry

\section{INTRODUCTION}

Local communities are ordinarily antagonized by several socio-economic challenges such as poverty, HIV and AIDS, tribalism, racism, drugs, domestic violence, crime, and more. ${ }^{1}$ Mayibuye community, like many other townships in South Africa (SA), is facing the above-mentioned socio-economic challenges. As a result, many people in this township still live in poverty, in shacks or tiny houses benefited from government-sponsored housing projects. In recognition of the above situation, and noting that the youth comprises a significant proportion of the Mayibuye community, the researcher found it necessary to study the relationship between

$1 \quad$ Mohamed Buheji \& Dunya A. Ahmed, “Investigating the importance of youth economy, ” International Journal of Current Advanced Research, Volume 6, Issue 3 (2017), 2405. 
community development and youth ministry in the Mayibuye community. For the study, six local churches from different denominations, that is, Pentecostal, charismatic, and mainline churches were selected. Their names are withheld for ethical reasons. This paper argues that the adversities described above co-exist with the continuous establishment of local churches in local communities. The results of this study are expected to contribute to the existing body of knowledge in areas such as Youth Ministry, Theology and Development, and or Community Development.

\section{METHODOLOGY}

The study applied Richard Osmer's model of theological interpretation, focusing on two of his tasks, namely descriptive-empirical and interpretive. ${ }^{2}$ Osmer's model offers the four tasks of practical theology, namely descriptive-empirical, interpretive, normative, and strategic tasks. The key objective of this model is to capacitate congregational leaders to systematically engage in practical theological interpretation of challenges confronting them in ministry. ${ }^{3}$ Moreover, this model is an interpretive guide for congregational leaders to interpret episodes, situations, and contexts theologically. ${ }^{4}$ Therefore, the model has been employed to understand precisely what is happening in youth ministry and community development contexts. The study was conducted in the Mayibuye section of Tembisa township in Gauteng Province of SA. The qualitative research approach employed included the description of the data collection process, sample selection, interviews, data analysis, and interpretation. The study used both document analysis and field data to determine the importance of youth ministry in community development. The purposive sampling technique was employed in selecting the interviewee participants. For the purpose of the study, six people were selected for interviews: three ministers and three youth leaders. All participants were eighteen years of age and above as the Constitution of South Africa states that any person under eighteen is a child. ${ }^{5}$ Participants were from different local churches operating in the Mayibuye section, Tembisa township, in Gauteng Province. The selection process was based on the assumption that since ministers and youth leaders occupy leadership positions, they would be able to give the required implicit information and answer the questions posed by the researcher. ${ }^{6}$

\section{FINDINGS AND DISCUSSION}

\section{Youth Situation in Mayibuye}

This section gives an overview of the situation in the Mayibuye community. It answers the question of what the current situation is. ${ }^{7}$

\section{Low level of education}

Information from the interviews indicated the lack of education as one of the prime challenges in Mayibuye. Education is essential to the community; thus, it should be recognized as a common good that needs to include issues such as gender equality, social justice, discrimination, and so forth. ${ }^{8}$ Friedrich Schweitzer embraces the above explanation by alluding that education is expected to change certain attitudes, values, and behaviours from the people, for example, to assist people in overcoming cruel behaviour and becoming people of good morals. ${ }^{9}$ On the contrary, a lack of knowledge in decision-making is a challenge in the Mayibuye community, especially when it comes to the youth sector. This is a massive problem for the community as education

Richard R. Osmer. Practical theology: An Introduction, (Grand Rapids: W.B. Eerdmans, 2008), 4.

Kevin G. Smith, "Review of Richard Osmer, Practical Theology: An introduction," The Journal of the Southern African

Theological Seminary, Vol 10, No.1 (2010), 99.

4 Smith, Review of Richard Osmer, 99.

5 The constitution of the Republic of South Africa (1996), 12.

6 Sarah J. Tracy, Qualitative Research Methods: Collecting evidence, crafting analysis, communicating impact. (2 ${ }^{\text {nd }}$ ed. John Wiley \& Sons, Inc, 2020), 83.

7 Osmer, Practical theology, 4.

8 United Nations Educational, Scientific and Cultural Organization. Rethinking education. Towards a global common good?, United Nations Educational, Scientific and Cultural Organization, (Paris, UNESCO Publishing, 2015 ), 11.

9 Friedrich Schweitzer, "Human dignity and education - A protestant view," HTS Teologiese Studies/ Theological Studies, Vol 72, No.4 (2016), 2. 
ought to empower people, specifically youth, on how to live together in a world characterised by diversity and pluralism. ${ }^{10}$ Churches, specifically in Mayibuye commenced a drive to enable their youth ministry arm offer proper education for both the ministry and society. Consequently, churches resorted to establishing informal education programmes in their youth ministry structures that impart skills like debate, research, presentation, et cetera. These skills have helped in community development; for example, research skills allow investigating and understanding the pressing issues within communities, while skills like debating allow unveiling and polishing available talents amongst the community. More effort can be put in by other stakeholders to reach a large population of the youth in the community.

\section{Lack of Professional Skills}

Lack of skills is the shortage of knowledge or the ability to do something properly. ${ }^{11}$ Participants flagged the lack of professional skills in the Mayibuye community as the contributing factor to the poor transformation. Lack of professional skills amongst young people in local communities is a great challenge. ${ }^{12}$ The participants stated that the situation is worse because even the people who are working started to lose their jobs because of new skills demand in the market. To elaborate this factor further, participants posited that local churches have introduced informal education in their youth ministry structures that impart young people with basic skills such as communication, marketing, presentation skills, and more. Yet, they are mindful that churches alone cannot solve this problem successfully; hence they appeal to other agencies to play their transformational role.

\section{Gender Inequality}

Ordinarily, this treatment comes from distinctions concerning biological, psychological, or cultural norms; they are either empirically grounded or socially constructed and women are generally treated unequally as compared to their male counterparts. ${ }^{13}$ Gender inequality is not a challenge only in local communities like Mayibuye, but a societal problem. For instance, Zulfqar Wani and Ruchi Dastidar view gender inequality as a curse for the society because it leads to loss of economic, social and political opportunities. ${ }^{14}$ Hence gendersensitive policies such as UNECE Policy for Gender Equality and the Empowerment of Women should be implemented to curb these abnormalities and create better opportunities for all, including women. ${ }^{15}$ Thus, these policies and programs would protect women from suffering exclusion and losing their dignity from the communities. ${ }^{16}$ The participants agreed that gender inequality wrecks communities tremendously, especially when it comes to the youth. For instance, one of the participants said that girls are overlooked when local contractors recruit labourers. The participants argued that girls are overlooked even when they have the necessary skills to do the job; according to them, local contractors only needed men. Participants also argued that this matter is a challenge even in churches. In their view, the lack of growth and development of women towards the higher church ranks as compared to men manifests this reality. Participants added that issues of Gender-Based Violence (GBV) against women and young girls in communities such as Mayibuye are fuelled by social evils like gender inequality.

10 Fazilah Idris, Zaharah Hassana, Azizah Ya'acob, Saran Kaur Gill \& Noor Aziah Mohd Awal, "The role of education in shaping youth's national identity,” Procedia - Social and Behavioral Sciences 59, Elser Ltd (2011), 444.

11 Macmillan Dictionary, https://www. Macmillandictionary.com.

12 Elvin Shava \& Maramura Tafadzwe Clementine, "A Descriptive Analysis of the Causes, Challenges and Effects of Skills Deficit on Youth Empowerment in South Africa," Journal of Social Science, Vol 49, No.1-2 (2016), 95.

13 Leepo J. Modise, "Women liberation in church and political organisation governance: Uniting Reformed Church in Southern Africa and African National Congress perspectives.” In die Skriflig, Vol 52, No.1 (2018), 3.

14 Zulfqar Wani \& Ruchi Dastidar, “Gender inequality - A Global issue,” International Journal of Research, Vol 05, Issue 19 (2018), 383.

15 UNECE, UNECE Policy for Gender Equality and the Empowerment of Women: Supporting the SDGS implementation in the UNECE region (2016-2020). (Swirtzerland: United Nations Publication, 2016), 17.

16 Gurhahoza Ghislaine N. \& Kakwata Frederick, "Gender parity: Legal foundations and theological issues in the Democratic Republic of the Congo," In die Skriflig, Vol 54, No.1 (2020), 2. 


\section{Unemployment}

Stats SA states that unemployment in SA staggered at 32.6\% during the first quarter in $2021 .{ }^{17}$ This high rate shows that unemployment is a severe problem in SA. In addition, youth unemployment in SA is staggering at $46.3 \%{ }^{18}$ Considering this report, participants viewed such a high unemployment rate in SA as the result of social problems in the communities and society. While the participants were unable to quantify the unemployment rate in Mayibuye, they cited it as a serious challenge. They said that many youths roam the streets with placards showing what they are willing to assist with, like lawnmowing, painting etc. This shows the high level of desperation for employment. Garth Aziz concurs with the participants' assertion, he further argues that youth ministry should take note of the changing dynamics in life such as crime, poverty, unemployment, and teenage pregnancy, to name but a few that affect young people and to provide measures to curb this negative trend. ${ }^{19}$

\section{Sexual-related Challenges}

Sexually related challenges include teenage pregnancy, HIV and AIDS which are social problems. Teenage pregnancy is a serious concern in the society as it is approximately $9 \%$ of female learners who fall pregnant between the ages of 16 and $18 .{ }^{20}$ Phillipa Strong poetically states that the alarming rate of youth pregnancies manifests that today's teenage girls are no longer changing their dolls and playing dress-up pretending that they are adults; they are actually playing the sexual roles of adults. ${ }^{21}$ The research participants alluded to the fact that teenage pregnancy is a concern in the Mayibuye community. In their arguments, it was evident that social challenges like poverty, alcohol, drugs, lack of parental guidance, and change of moral values are the main causes of teenage pregnancy. Moreover, this sexually related challenge exposes teenagers to HIV and AIDS. These diseases have been acknowledged as global diseases that have infected many people, predominantly young people. Like any other local community, the Mayibuye community is experiencing this social-related challenge. According to the participants, the community, particularly youths, are grappling with the HIV and AIDS pandemic, but some interventions such as condom distribution and awareness campaigns are randomly conducted in the community. Most importantly, the availability of medication makes a difference to this disease.

\section{Substance abuse}

Alcohol abuse has caused unsteadiness to many households, resulting in divorce and related problems that affect the children of the concerned families. Solomon Ademiluka argues that uncontrolled drinking is the source of violence and other social ills in local communities. ${ }^{22}$ The interaction with participants revealed that alcohol abuse contributes to domestic violence and GBV in the Mayibuye community. Participants also added that churches and the communities are losing great talents to alcohol and drugs. Nalah Bala and Akawu Monday also add to this by stating that drug abuse is common amongst youth in local communities and society. ${ }^{23}$ Nonetheless, this substance abuse is dangerous for teenagers because if a young person is using drugs, developing an addiction is exceptionally high during the teenage years. Drug abuse among young people is an ever-increasing reality and is one of the most significant contributing factors to domestic violence within families and communities. ${ }^{24}$ For students, drug abuse leads to memory loss, poor attendance,

\footnotetext{
17 Statistics South Africa, Quarterly Labour Force Survey - Q1:2021. (Pretoria: Stats SA, 2021), 1.

18 Statistics South Africa, Quarterly Labour Force Survey - Q1:2021, 1.

19 Garth Aziz, "Toward a contemporary understanding of youth ministry as a descriptive agency," In die Skriflig, Vol 53, No.1 (2019), 2.

20 Fazel E. Freeks, “An assessment of the LIFEPLAN programme as a possible approach to Christian formation," Verbum et Ecclesia, Vol 38, No.1 (2017), 4.

21 Philippa Strong, "Effective Youth Ministry: Theology-driven in a Cultural Context," In die Skriflig, Vol 49 No.1 (2015), 8.

22 Solomon O. Ademiluka. 2020, "Proverbs 23:29-35 in the light of the role of the church in Nigeria in curbing alcoholism," Verbum et Ecclesia, Vol 41, No.1 (2020), 8.

23 Nalah Bala \& Akawu Monday, "Drug Use and Youth Restiveness and its Implications to Students Living Within Communities of Nasarawa State University, Keffi-Nigeria," European Academic Research, Vol 1, Issue 12 (2014), 5236.

24 Christo Thesnaar, "Healing the Scars: A Theological-hermeneutical Analysis of Violence," Scriptura Journals, (2011), 25.
} 
and performance, and difficulty in concentration. ${ }^{25}$ The research participants expatiated on the above assertion by stating that in Mayibuye, there is a common drug called 'nyaupe' that is abused. As a result of this trend, young people abandon classes, and most young people in the community do not complete grade 12 and drop out in lower classes.

\section{Illicit Conduct}

Coupled with substance abuse and frustration brewed by unemployment, violence seems to be another big challenge in this community. Violence in Mayibuye is rife and is a problem as it endangers peoples' lives and hampers the economy. Christo Thesnaar accentuates that violence brings distressing effects on the victims, communities, and society at large. ${ }^{26}$ Participants deliberated that the community is lagging behind in development because some development agents are sceptical about bringing development projects in Mayibuye because of high violence and crime in the area. Crime and violence are intertwined as they are the products of deviant behaviour. Nevertheless, crime is anti-social behaviour that includes rape, burglary, drunken driving, murder, robbery, etc. and SA is experiencing a high crime rate as compared to other countries in the world. ${ }^{27}$ This high crime rate is perpetuated by the population's limited access to socio-economic resources such as better education, training, and employment. ${ }^{28}$ In explaining the community's crime level, the participants argued that people are even scared to walk around, especially at night.

\section{Interpretation of Christian Youth (Ministry) Involvement}

This section answers Richard Osmer's question, why is it happening? To answer this question, the study used theories of arts and sciences to clarify youth ministry and community development contexts in the Mayibuye community.

\section{Social Justice}

Social justice is a fair and equitable distribution of power, resources, and obligations in the community, that is, to all people regardless of race or ethnicity, age, gender, ability status, sexual orientation, and religious or spiritual background. ${ }^{29}$ South Africa is among other countries that are facing socio-economic difficulties. ${ }^{30}$ Some of the challenges stated in the previous section relate to social justice deficiencies. For instance, issues of gender equality and unemployment tend to be high in Mayibuye because of the community's perceptions about the distribution of power resources and obligations. The issue of neglecting female youth by local contractors in offering job opportunities is one example of inequitable distribution of resources in this community. Issues related to social justice that impact people's daily lives are likely to change if churches as transformation agents adopt a culture of engaging young people. In summary, the latter would be effective when churches, alongside their youth ministries, play a more significant role in promoting and ensuring that social justice is being served in local communities. ${ }^{31}$

\section{Social Cohesion}

Social cohesion is the capacity of the community to ensure the welfare of all its members and minimize

25 Ifeoma P. Okafor, "Causes and consequences of drug abuse among youth in Kwara State, Nigeria," Canadian Journal of family and youth", Vol 12, issue 1 (2019), 157.

26 Thesnaar, Healing the Scars, 26.

27 Qakathekile Mathuthu, "Crime in South Africa," South Africa Public Crime, Law and Social changes Law Journal, Vol 1, Issue 1 (2019), 4.

28 Garth Aziz, “Age does not determine influence: A consideration for children in ministerial service,” HTS Teologiese Studies/ Theological Studies, Vol 76, No.2 (2020), 2.

29 Lukwikili Mangayi, "Mobilising the Local Church for Social Justice and Reconciliation: Theological /Missiological Reflections on the Ministries of the Baptist Union of Southern Africa (1996 - 2011)," The South African Baptist Journal of Theology, (2014), 132.

30 Salaelo T. Kgatla, "Relationships are building blocks to social justice: Cases of biblical justice and African Ubuntu," HTS Teologiese Studies/Theological Studies, Vol 72 No. 1 (2016), 2.

31 Elisabet Le Roux, Elina Hankela, \& Zahraa McDonald, "Social justice required: Youth at the margins, churches and social cohesion in South Africa,” HTS Teologiese Studies/ Theological Studies, Vol 74, No.3 (2018), 8. 
disparities in the community. It also provides that the community can secure the long-term well-being of its members; this includes respect for human dignity, personal and collective independence, equitable access to limited available resources, and responsible participation of all community members. ${ }^{32}$ The preceding section illustrated that social cohesion remains a considerable challenge in Mayibuye as the area faces adversities like gender inequality, which are drawbacks to social cohesion. It might benefit the community if other stakeholders like churches, youth, and Faith-Based Organisations (FBOs) collaborate in the area. The voice of the youth is significant in social cohesion, which has been seen as the comfort zone for senior generations to cling to. ${ }^{33}$ Besides, in South Africa, social cohesion is an important issue, given the country's history of social division, separation and strife, and the policies of successive colonial and apartheid administrations, which deliberately placed the welfare of the minority above that of the majority. ${ }^{34}$

\section{Social Capital}

Social capital is the network of relationships amidst community members who live and work together to ensure that their community functions efficiently and effectively. Social capital is essential to any community because it empowers and influences people to get ahead and improve their lives. The participants alluded that social capital is the ingredient to loosen differences such as religion, race, gender, and so on and creates one community that works for one goal, that is, to develop better communities and society. During the interviews, participants acknowledged social capital as a key to both youth ministry and community development. Unfortunately, the latter is different in the Mayibuye area as the previous sections have illustrated issues such as low level of education, lack of skills, and gender inequality as predominant in the area. As such issues persist, it would be impractical for social capital to be effective. For this reason, participants appealed to churches and other local transformational agents to play their critical role of creating social capital to enable community members address their issues through collective action. Some participants also argued that some of their church branches are in awkward areas with limited infrastructure. Still, social capital as a resource enables them to effect changes within such challenges. Anita Cloete agrees with the position and argues that social capital is the summation of individuals who work together towards common goals in any form of social network that would yield better results for their community. ${ }^{35}$ In a nutshell, social capital requires people to nurture and maintain relationships with other people regardless of culture, religion, beliefs, race, and more.

\section{Sustainability Theory}

Sustainability is generally the process of continuity. Asia Iqbal and Afaq Khan define sustainability as the element of development that accomplishes the requirements of the present without compromising future needs. ${ }^{36}$ In other words, the implications of today's development should be long-term. Sustainability is the most famous community principle because it combines community development with components that are economical, social, and the environmental. ${ }^{37}$ In addition, this principle holds developmental goals with substantial opportunities for improving the quality of life and health of all humankind in all ages. The various challenges as highlighted still remain a challenge in the Mayibuye community. Therefore, it would not be possible for the people to sustain the development projects in their community. In addition, a low level of education in the area leads the people to struggle to analyse the economic trends. In Wan Yahya's view,

32 Council of Europe, Concerted Development of Social Cohesion Indicators: Methodological Guide. (Strasbourg: Council of Europe Publishing, 2005), 9.

33 McGlory, Speckman, "Student leadership and advocacy for social cohesion: A South African perspective," African Journal on conflict resolution, Vol 15, No 3 (2015), 77.

34 Fébé Potgieter-Gqubule \& Nonkululeko Ngcobo, "The State of Youth in South Africa: Social dynamics," Centre for poverty employment and growth, Human Sciences Research Council (HSRC) (2009), 10.

35 Anita Cloete, "Social cohesion and social capital: Possible implications for the common good," Verbum et Ecclesia, Vol 35, No. 3 (2014), 2.

${ }^{36}$ Asia Iqbal \& Afaq A. Khan, "Inclusive and sustainable community development and poverty reduction: An empirical study of Sindh, Pakistan.” IOP Conference Series: Earth and Environmental Science, Vol 511, Issue 1 (2020), 5.

37 Tunde V.Bakare, "Integrating Sustainability Principles into Community Development and Peace Efforts in Nigeria," Journal of Emerging Trends in Educational and Policy Studies, (2018), 220. 
young people's involvement is vital as they are the pillars and driving force to sustainable developmental goals. ${ }^{38}$ The training, facilitation, and the provision of sustainability by local churches through their youth ministry structures would be pivotal to the development of local communities.

\section{Self-determination Theory}

Self-determination is the aptitude to think for oneself and to take actions that are relevant to the ideas. ${ }^{39}$ Considering the importance of this psychological construct, Eadaoin Hui and Sandra Tsang allude that selfdetermination needs to be promoted as early as at the primary school level. ${ }^{40}$ Participants have indicated that young people in the Mayibuye area are not interested in education because of the money gotten from peddling drugs and drug abuse. The little interest in education contributes to the youth not fully realizing their self-determination or not recognizing it at all. As they stay away from learning institutions, many youths lose out on the possibility of receiving formal education, which could contribute to their self-determination. Selfdetermination should encourage the validity of moral values such as truth, freedom, charity, and more that promote a better life for all. In other words, it should be an educational goal for all students with or without disabilities. However, schools need to collaborate with other local institutions like churches. Churches through youth ministry teachings need to promote self-determination amongst young people. Accordingly, churches have to ensure that Christian teachings that include Christianity's conceptual support for ideals of freedom and self-determination are encouraged in local churches and communities. ${ }^{41}$

\section{The Contribution of Youth Ministries to Community Development Promoting Moral Values}

Values are generally acknowledged as perceptive structures that guide people to make a sense between right and wrong. In addition, values play an indispensable role in encouraging and guiding human actions. ${ }^{42}$ Therefore, values are fundamental to give structure to a life of a person. Given its contribution to the promotion of moral values, the church could play a significant role in subduing illicit conduct by extolling godly principles in the youth. In this way incidents of violence, substance abuse and sexual immorality may be outnumbered by the rise of healthy behavior among the youth. The reason is that these people represent the church, and most importantly, they are called to be God's representatives. Hence they should demonstrate the highest standards of ethical behaviour. If not, it would be irrational for them to acquire any moral authority from the church and community. ${ }^{43}$ All the participants underlined the significance of moral values among people, most notable among believers. Their views are that moral values should be vigorously enforced inside and outside the walls, particularly in youth ministry.

\section{Enhancing Respect for Others}

Respect promotes equality that gives a platform for all to be engaged in activities that affect well-being and welfare. Thus, all community segments need to be given opportunities to contribute to the decisionmaking process and not be onlookers whose lives are passive and compelled only to comply. Generally, poor backgrounds and life challenges confronting young people bring frustrations that lead them to lose self-respect and respect for others, especially if they see their dreams vanishing. As a result, such situations contribute to youth engaging in a life of drugs, sex, gambling, et cetera. Christina Landman and Hannelie

\footnotetext{
38 Wan K. Yahya. Engaging Youth Participation in Making Sustainability Work. In: Leal Filho W., Wall T., Azul A., Brandli L., Özuyar P. (eds) Good Health and Well-Being. Encyclopedia of the UN Sustainable Development Goals, (Springer, Cham 2020), 3.

39 Eadaoin K.P. Hui and Sandra K.M. Tsang, "Self-Determination as a Psychological and Positive Youth Development Construct," The Scientific World Journal, (2012), 1.

40 Hui and STsang, Self-Determination as a Psychological and Positive Youth Development Construct, 5.

41 Drew Smith, "Urban marginality, religious liminality, and the black poor," HTS Teologiese Studies/Theological Studies, Vol 71, No.3 (2015), 3.

42 Daphna, Oyserman, “Values, Psychology of. In: James D. Wright (editor-in-chief), ” International Encyclopedia of the Social \& Behavioral Sciences, 2nd edition, Vol 25 (2015), 36.

43 Wim, Dreyer, "Church, mission and ethics. Being church with integrity," HTS Teologiese Studies/ Theological Studies, Vol 72, No.1 (2016), 5.
} 
Yates posit that the absence of respect among communities is the greatest challenge in local communities. ${ }^{44}$ It seems like other role players such as parents and forms of governance are struggling to promote this value. For this reason, the just mentioned authors appeal to the local churches to fulfil this role as they are perceived as role players capable of inculcating a lifestyle of hopelessness. People need to respect themselves first before they think of respecting others, as it would be difficult to respect others if you cannot respect yourself first.

\section{Driving Service with Integrity}

The word 'integrity' originates from the Latin adjective "integer," meaning whole. ${ }^{45}$ A person with integrity does not pretend and is not compromised or divided. In other words, integrity expresses completeness, wholeness, or entireness. ${ }^{46}$ Kelebogile Resane concurs with the above assertions; however, he adds on the perspective by commenting that, in the Christian view, integrity is regarded as the driving force, specifically in critical areas like counselling, caring, shepherding, protecting the flock, and so forth. ${ }^{47}$ Participants expressed that believers should be people of integrity and be honest as they are entrusted with sharing God's word. Additionally, they postulated that youth ministry has to be developed to cultivate the culture of integrity, which is, to perceive elders as trustworthy and ethical.

\section{Cultivation of Hope}

Hope is a positive attitude of mind with expectant outcomes associated with events and circumstances in life experiences. ${ }^{48}$ Through hope, people feel self-assured in trying out new things, hoping for positive results. In this essence, hope is the critical value of community development because it supports people to look forward to the future. Moreover, hope gives the courage to stand and face difficult times by transforming the present in mind. The participants recognize hope as the positive attitude of mind with a belief in positive outcomes shortly amid life experiences. For them, churches should motivate people, notably young people, to build and nature relationships with other young people in the community. This is the strategy that should be adopted to cultivate hope amongst young people. Regrettably, participants asserted that most young people in the community are victims of drugs and alcohol because they lack hope in their lives. Considering the above, Christians as bearers of God's hope should play their distinct role of inculcating hope in communities. Furthermore, they need to be engaged during hard times, like death, because they could bring hope as therapy during the mourning phase. ${ }^{49}$

\section{Enhanced Collaboration}

Enhanced collaboration is one of the benefits of youth involvement in community development. Participants stressed that collaboration is essential to the development process as it brings solidarity to the community. For them, churches ought to engrain total and active citizenship collaboration by using their youth ministry arm. In supporting the above assertion, Stephan de Beer alludes that collaboration is vital in the community development process as it permits the incorporation of diverse resources and institutional assets to achieve a collective imagination. ${ }^{50}$

Therefore, the community development process has to involve collaboration between role players like development agencies, government, and all community segments, including the youth. During the

44 Christina Landman \& Hannelie Yates, "The church should teach us to do respect: Voices from rural youth in Mpumalanga, South Africa," HTS Teologiese Studies/ Theological Studies, Vol 74, No.3 (2018), 4.

45 Kelebogile, T. Resane, "Servant leadership and shepherd leadership: The missing dynamic in pastoral integrity in South Africa today," HTS Teologiese Studies/ Theological Studies, Vol 76, No.1 (2020), 4.

46 Resane, Servant leadership and shepherd leadership, 4.

47 Resane, Servant leadership, 1.

48 Seyed, M.H. Shirvani, "Raising Hope" in Quran and psychology," HTS Teologiese Studies/Theological Studies, Vol 74, No.1 (2018), 1.

49 Dion A Forster, "What hope is there for South Africa? A public theological reflection on the role of the church as a bearer of hope for the future," HTS Teologiese Studies/ Theological Studies Vol 71, No.1 (2015), 11.

50 Stephan F. de Beer, "Faith-based action and urban regeneration," HTS Teologiese Studies/ Theological Studies, Vol 74, No.3 (2018), 4 . 
development process, local communities need to embrace the confrontational approach to acknowledge their pressing issues. However, it is essential for the role players to be united because if they function in opposition and contrast to each other, it would be impossible for the development to succeed. Consequently, the collective cries of the poor might seemingly fall on deaf ears as their needs would not be addressed. ${ }^{51}$

\section{Active Citizenship}

Active citizenship is when people are not reluctant of taking responsibility for their well-being. This process can be taken as a form of individualized action or a collective endeavour. Participants emphasised that active citizenship is imperative for effective community development as all segments of the community, including youth need to be recognized as active participants. In other words, this process can be a cooperative or collaborative endeavour, and it reflects the positive results yielded in community development. However, for a positive community development process amidst local communities, teachers, parents, classmates, and friends in peer groups have to be acknowledged as critical social agents in transforming young people into active and participatory citizens. ${ }^{52}$ As active citizens, young people would foster fruitful interactions and prioritize duty of care to others over other concerns as ingredients of transformation.

Young people could transform local communities better than every sector in the community as they can employ creative approaches and solutions to address the needs of their communities. Youth possess several skills needed to transform communities. The benefit of involving youth in the community development process is to choose the most pressing issues vital to the community. Moreover, young people would select issues through a collective decision-making process rather than dealing with matters selected randomly or predetermined. ${ }^{53}$ Participants argued that there is little to say about the transformation as the benefits in the Mayibuye community. For them, transformation is still in progress. Even though they see the signs, it was still early for them to share any information.

\section{RECOMMENDATIONS}

The findings of this study lead to the following recommendations:

- Scholars need to consider conducting further empirical studies on youth ministry involvement in community development in various local communities.

- The local religious communities and government authorities ought to enhance their collaboration in dealing with socio-economic challenges among local communities.

- For the sustainability of community development processes, churches and other development stakeholders should engage young people at the foundation and planning stages of the development projects.

\section{CONCLUSION}

This article illuminated that Christian youth ministry involvement in community development activities is essential in local communities, specifically in Mayibuye. This claim is informed by findings that emanated from a qualitative study that employed Osmer's theory of theological interpretation. The study used the descriptive-empirical task to collect and analyse data from the theory. As per guidance from this theory, the study used theories of arts and sciences to interpret the data. The study identified gaps and recommended further empirical studies on youth ministry and community development among local churches. The researcher believes that the findings of this study will contribute to the existing body of knowledge in areas such as Youth Ministry, Theology and Development, and or Community Development.

51 Stephan.F. de Beer, “Absence, presence, remembrance: A theological essay on frailty, the university and the city," Verbum et Ecclesia, Vol 34, No.1 (2013), 4.

52 Shun N.G. Wing, "Youth Civic Participation: do socialising agents matter?" Citizenship, Social and Economics Education, I Vol 13, No. 2 (2014), 127.

53 Brian D. Christens \& Tom Dolan, "Interweaving Youth Development, Community Development, and Social Change Through Youth Organizing," SAGE Journals, Vol 43, No.2 (2011), 529. 


\section{BIBLIOGRAPHY}

Ademiluka, Solom O. "Proverbs 23:29-35 in the light of the role of the church in Nigeria in curbing alcoholism." Verbum et Ecclesia, Vol 41, No.1 (2020): 1-11.

Aziz, Garth. "Toward a contemporary understanding of youth ministry as a descriptive agency." In die Skriflig, Vol 53, No.1 (2019): 1-7.

Aziz, Garth. "Age does not determine influence: A consideration for children in ministerial service”. HTS Teologiese Studies/ Theological Studies, Vol 76, No.2 (2020): 1-7.

Bakare, Tunde V. "Integrating Sustainability Principles into Community Development and Peace Efforts in Nigeria." Journal of Emerging Trends in Educational and Policy Studies (2018): 220-228.

Bala, Nalah \& Monday, Akawu. "Drug Use and Youth Restiveness and its Implications to Students Living Within Communities of Nasarawa State University, Keffi-Nigeria.” European Academic Research, Vol 1, Issue 12 (2014), 5236-5251.

Buheji, Mohamed \& Ahmed, A. Dunya. "Investigating the importance of youth economy." International Journal of Current Advanced Research, Volume 6, Issue 3 (2017), 2405 - 2410.

Christens, Brian D. \& Dolan, Tom. 2011. Interweaving Youth Development, Community Development, and Social Change Through Youth Organizing. SAGE Journals, Vol 43, No.2 (2011): 528-548.

Cloete, Anita. "Social cohesion and social capital: Possible implications for the common good." Verbum et Ecclesia, Vol 35, No. 3 (2014): 1-6.

De Beer, Stephan.F. "Absence, presence, remembrance: A theological essay on frailty, the university and the city." Verbum et Ecclesia, Vol 34, No.1 (2013): 1-9.

De Beer, Stephan.F. "Faith-based action and urban regeneration." HTS Teologiese Studies/ Theological Studies, Vol 74, No.3 (2018): 1-11.

Council of Europe. Concerted Development of Social Cohesion Indicators: Methodological Guide. (Strasbourg: Belgium, Council of Europe Publishing, 2005): 1-234.

Forster, Dion A. "What hope is there for South Africa? A public theological reflection on the role of the church as a bearer of hope for the future." HTS Teologiese Studies/ Theological Studies, Vol 71, No.1 (205): 1-13.

Freeks, Fazel E. "An assessment of the LIFEPLAN® programme as a possible approach to Christian formation." Verbum et Ecclesia, Vol 38, No.1 (2017): 1-10.

Gurhahoza, Ghislaine N. \& Kakwata, Frederick. "Gender parity: Legal foundations and theological issues in the Democratic Republic of the Congo." In die Skriflig, Vol 54, No.1 (2020): 1-9.

Hui, Eadaoin K.P. \& Tsang, Sandra K.M. "Self-Determination as a Psychological and Positive Youth Development Construct." The Scientific World Journal, (2012): 1-7.

Kgatla, Salaelo T. "Relationships are building blocks to social justice: Cases of biblical justice and African Ubuntu." HTS Teologiese Studies/Theological Studies, Vol 72, No.1 (2016): 1-6.

Idris Fazilah, Hassana Zaharah, Ya'acob Azizah, Gill Saran Kaur \& Awal Mohd Aziah Noor. "The role of education in shaping youth's national identity." Procedia - Social and Behavioral Sciences 59, Elser Ltd (2011): 443 - 450.

Iqbal, Asia. \& Khan, Afaq A. "Inclusive and sustainable community development and poverty reduction: An empirical study of Sindh, Pakistan." IOP Conference Series: Earth and Environmental Science, Vol 511, Issue 1 (2020): 1-10.

Landman, Christina \& Yates, Hannelie. "The church should teach us to do respect: Voices from rural youth in Mpumalanga, South Africa.” HTS Teologiese Studies/ Theological Studies, Vol 74, No.3 (2018): $1-8$.

Le Roux Elisabet, Hankela Elina \& McDonald, Zahraa. "Social justice required: Youth at the margins, churches and social cohesion in South Africa." HTS Teologiese Studies/ Theological Studies, Vol 74, No.3 (2018): 1-8.

Mangayi, Lukwikili. "Mobilising the Local Church for Social Justice and Reconciliation: Theological/ Missiological Reflections on the Ministries of the Baptist Union of Southern Africa (1996 - 2011)." The South African Baptist Journal of Theology (2014): 132-149. 
Macmillan Dictionary. https://www. Macmillandictionary.com.

Qakathekile, Mathuthu. "Crime in South Africa." South Africa Public Crime, Law and Social changes Law Journal, Vol 1, Issue 1 (2019): 1-18.

Modise, Leepo J. "Women liberation in church and political organisation governance: Uniting Reformed Church in Southern Africa and African National Congress perspectives." In die Skriflig, Vol 52, No.1 (2018): 1-8.

Okafor, Ifeoma P. "Causes and consequences of drug abuse among youth in Kwara State, Nigeria." Canadian Journal of family and youth, Vol 12, Issue 1 (2019): 147-162.

Osmer, Richard R. Practical Theology: An introduction. (Grand Rapids: W.B. Eerdmans, 2008): 1-246.

Oyserman, Daphna. Values, Psychology of. In: James D. Wright (editor-in-chief), International Encyclopedia of the Social \& Behavioral Sciences, $2^{\text {nd }}$ edition, Vol 25 (Oxford: Elsevier, 2015): 36-40.

Potgieter-Gqubule, Fébé \& Ngcobo, Nonkululeko. The State of Youth in South Africa: Social dynamics. Centre for poverty employment and growth. (Human Sciences Research Council, 2009): 1-45.

Resane, Kelebogile T. "Servant leadership and shepherd leadership: The missing dynamic in pastoral integrity in South Africa today.” HTS Teologiese Studies/ Theological Studies, Vol 76, No.1 (2020): 1-8.

Shava, Elvin \& Clementine, Maramura Tafadzwe. "A Descriptive Analysis of the Causes, Challenges and Effects of Skills Deficit on Youth Empowerment in South Africa.” Journal of Social Science, Vol 49, No.1-2 (2016): 93-100.

Schweitzer, Friedrich. "Human dignity and education - A protestant view." HTS Teologiese Studies/ Theological Studies, Vol 72, No.4 (2016): 1-8.

Shirvani, Seyed M.H. "Raising Hope in Quran and psychology.” HTS Teologiese Studies/Theological Studies, Vol 74, No.1 (2018): 1-6.

Smith, Drew. "Urban marginality, religious liminality, and the black poor." HTS Teologiese Studies/ Theological Studies, Vol 71, No.3 (2015): 1-8.

Smith, Kevin G. "Review of Richard Osmer, Practical Theology: An introduction." The Journal of the Southern African Theological Seminary, Vol 10, No.1 (2010): 99-113.

Speckman, McGlory. "Student leadership and advocacy for social cohesion: A South African perspective." African Journal on conflict resolution, Vol 15, No 3 (2015): 61-84.

Statistics South Africa. Quarterly Labour Force Survey - Q1:2021 (Pretoria: Stats SA, 2021): 1-2.

Strong, Philippa. "Effective Youth Ministry: Theology-driven in a Cultural Context." In die Skriflig, Vol 49, No.1 (2015): 1-9.

The constitution of the Republic of South Africa, 1996: 1-107.

Thesnaar, Christo. "Healing the Scars: A Theological-hermeneutical Analysis of Violence." Scriptura Journals, Scriptura 106 (2011): 26-37.

Tracy, Sarah J. Qualitative Research Methods: Collecting evidence, crafting analysis, communicating impact. ( $2^{\text {nd }}$ ed. John Wiley \& Sons, Inc. 2020): 1-400.

UNECE. UNECE Policy for Gender Equality and the Empowerment of Women: Supporting the SDGS implementation in the UNECE region (2016-2020). (Swirtzerland: United Nations Publication, 2016), 1-34.

United Nations Educational. Scientific and Cultural Organization. Rethinking education. Towards a global common good? United Nations Educational, Scientific and Cultural Organization. (Paris, UNISCO Publishing, 2015): 1-85.

Wani, Zulfqar \& Dastidar, Ruchi. "Gender inequality - A Global issue.” International Journal of Research, Vol 05, Issue 19 (2018): 383-395.

Wing, Shun N.G. "Youth Civic Participation: Do socialising agents matter?" Citizenship, Social and Economics Education, Vol 13, No. 2 (2014): 121-131. 


\section{ABOUT AUTHOR}

Mawethu Msebi is a licensed Minister at the Reformed Presbyterian Church in Southern Africa and a registered Religious Specialist with the Association of Christian Religious Practitioners in South Africa. He holds an MTh in Practical Theology from the University of Pretoria, South Africa, and a Master of Business Administration (MBA) from the University of Reading, United Kingdom. He is currently doing a PhD at the University of Pretoria. He is also a Business Accountant in Practice with the Southern African Institute for Business Accountants. His research interests include youth ministry and community development. 